\title{
Poster 1008: Dialyzable leukocyte extracts as adjuvant treatment for allergic rhinitis
}

\author{
Toni Angela Homberg ${ }^{1 *}$, Rodolfo Ivan Lara², Sonia Mayra Pérez-Tapia', María Del Carmen Jiménez Martínez ${ }^{3}$ \\ From 2013 WAO Symposium on Immunotherapy and Biologics \\ Chicago, IL, USA. 13-14 December 2013
}

\section{Background}

Dialyzable leukocyte extracts (DLE) are human blood derived peptides less than $12 \mathrm{kDa}$ in size. DLE are hypothesized to induce a TH1 response, which makes them useful in the treatment of allergic disease. The purpose of this study was to determine the changes in symptomatology of patients with moderate and severe allergic rhinitis treated with standard treatment plus DLE.

\section{Methods}

We analyzed the clinical files of 68 patients receiving dialyzable leukocyte extracts as adjuvant treatment for moderate to severe allergic rhinitis in the period between 2009 and 2013, at our immunology department. All patients receiving DLE signed an informed consent as part of a running protocol (IC-12-001) authorized by the ethics committee and health department. Patients had different standard treatments for allergic rhinitis, such as antihistamines, nasal corticosteroids, leukotriene inhibitors and immunotherapy in varying combinations. Oral DLE was added to standard treatment in patients that remained symptomatic. The initial DLE dose varied between 1 and 2 Units (5mL/Unit) per week.

\section{Results}

$28(53.8 \%)$ female and $24(46.2 \%)$ male patients ages 0 - 64 with a mean age of $17.3 \pm 17.5$ yrs with moderate to severe allergic rhinitis added DLE to their treatment. After 1 to 5 months, 52 (76.5\%) reported improved symptoms, $11(16.2 \%)$ abandoned treatment, 5 (7.4\%) reported no improvement. No patients presented severe adverse effects. Of the 52 patients who reported improvement, 6 (11.5\%) were asymptomatic, 32 (61.5\%) mentioned general improvement of symptoms, 4 (7.7\%)

${ }^{1}$ Instituto Politécnico Nacional, Mexico City, Mexico

Full list of author information is available at the end of the article reported only decreased nasal congestion, 13 (25\%) reported less frequent upper respiratory infections. 2 patients (3.8\%) with concomitant asthma suspended the use of bronchodilators.

\section{Conclusions}

DLE may be beneficial as adjuvant treatment for allergic rhinitis. Although patient self-reported improvement is subjective, this study lays the ground for more objective measurements of drug response in the future. Interestingly, it helped decrease the use of bronchodilators in 2 cases with concomitant asthma.

\section{Authors' details}

'Instituto Politécnico Nacional, Mexico City, Mexico. "2Conde de Valenciana" Foundation, Mexico City, Mexico. ${ }^{3}$ Universidad Nacional Autónoma de México, Faculty of Medicine, Mexico City, Mexico.

Published: 3 February 2014

doi:10.1186/1939-4551-7-S1-P5

Cite this article as: Homberg et al:: Poster 1008: Dialyzable leukocyte

extracts as adjuvant treatment for allergic rhinitis. World Allergy

Organization Journal 2014 7(Suppl 1):P5.

Submit your next manuscript to BioMed Central and take full advantage of:

- Convenient online submission

- Thorough peer review

- No space constraints or color figure charges

- Immediate publication on acceptance

- Inclusion in PubMed, CAS, Scopus and Google Scholar

- Research which is freely available for redistribution 